\title{
Reproductive Trends in Cebu Cattle Grazing Rice Crop Residues in Colombian Tropical Dry Forest
}

\author{
Elisa Sierra-Montoya ${ }^{1}$, Rolando Barahona-Rosales ${ }^{1}$, Z. Tatiana Ruíz-Cortés ${ }^{2}$ \\ ${ }^{1}$ National University of Colombia, Medellín, Colombia \\ ${ }^{2}$ Faculty of Agrarian Sciences, Group of Research BIOGÉNESIS, University of Antioquia, Medellin, Colombia \\ Email: elsierramo@unal.edu.co
}

Received August 2013

\begin{abstract}
The objective of this study was to describe the trend of reproductive performance of primiparous and multiparous cows that grazed rice crop residues located in a Dry Tropical Forest of Colombia, taking into account the rainfall pattern of the place. In this study, 89 primiparous and 309 multiparous Cebu cattle records were analyzed. Mean, mean standard deviation for age at first calving and open days of primiparous Cebu cattle were $41.05 \pm 1.85$ months and $269.7 \pm 36.25$ days respectively. Confidence intervals (95\%) for both reproductive parameters were 36.8 - 45.3 months and 202.7 - 336.6 days respectively. For multiparous Cebu cattle, the mean and mean standard deviation for open days and calving interval were $245.6 \pm 36.8$ days and $17.5 \pm 0.9$ months respectively. Confidence intervals 207.1 - 366.9 days and 13.9 20.7 months respectively. The mean rainfall since 1999 until 2012 was $1202 \mathrm{~mm}$ per year. The reproductive trend of the primiparous cattle showed an increasing behavior of age at first calving since 1999 until 2012, that can possibly be explained due to the decreasing behavior of the rainfall throughout the years, that can affect the nutritional value and offer of the grass that can grow in the borders of the crop, such as Guinea and Star grass, and eventually affect the body condition and weight necessary to be ready for the first estrous. An inverse behavior of open days occurred, showing a decreased trend along the last years of research. This fact could have happened due to the intensive use of the enriched rice straw with urea and molasses lately. Regarding to the reproductive trend of the multiparous cattle, there is no an evident pattern of it. Factors such as rainfall, temperature, nutrition and management should have affected it. Further research on this topic is needed.
\end{abstract}

Keywords: Rice Crop Residue; Reproduction; Cebú Herd

\section{Introduction}

In 2012, Colombia (South American) has a bovine livestock of 20.432.140. The beef production orientation is represented by $49.6 \%$, almost half of the herd, and it represents a very important economic income for the country.

Recent concern about the reproductive performance of these beef and double purpose cattle has increased scientific research. Free Trade Agreements between Colombia and other countries such as the US and EU and policies as the Strategic Arrangement of the Colombian Cattle Herd 2019, demand products as meat of great quality. Lately, accelerated demographic growth and urbanization (FAO, 2009) (Delgado, Ehui, \& Cour, 1999) results in the raising of the per capita income, triggering the demand of meat and milk products. In order to achieve the goal of beef productivity, Colombian cattle reproductive performance must be enhanced taking into account nutrition and reproductive management as the main issues to improve.

A considerable amount of beef cattle of the Colombian herd grazes low quality forages and crop residues, as rice and maize. These crops residues have severe deficiencies in protein, energy and minerals contents, which can affect the reproductive performance of beef cattle. This herd has specific reproductive performance due to nutrition, management and climatic variables, but published analyzed data are missing.

Data from a rice producer farm that has Cebu (Bos indicus) cows located in Alvarado, Tolima, Colombia was collected between 1999 and 2012, with the main objective of describing the trend of reproductive development of primiparous and multiparous cows including rainfall patterns.

\section{Materials and Methods}

Data were obtained from a beef herd of the Hacienda Calicanto, a 170 hectares farm located in the municipality of Alvarado, Tolima, Colombia, at 439 meters above the sea level, in a life zone of Dry Tropical Forest (Holdrige, 1967), The average temperature was $26^{\circ} \mathrm{C}$, with a bimodal rainfall pattern during the year; almost 8 months had low pluviosity. Most of the land is dedicated to plant rice crops. When rice crops were harvested, Cebu cattle were introduced to graze the residues of the crop: the straw, with the main purpose of reducing the residue and also incorporing it to the soil through trampling, for almost 4 or 5 months. The animals were supplemented with amonificated rice straw, which means that the bales of rice straw were enriched with a mixture of water, molasses and urea. The water was ad libittum consumed. The Cebu cattle estrous was visually detected by observations of the sire with penis deviation, and registrated; 12 hrs later, artificial insemination was performed as the main reproductive event registered in the farm. Confirmation of pregnancy was done by rectal palpation every 6 months. The cows give birth to calf in the rice field; calves were suckling until 7 or 8 months, when males were sold and females were retained to replace the old cows. 
Reproductive events from 1999 through 2012 of this Cebu cows were used, including primiparous $(n=89)$ and multiparous $(n=309)$ ones. Variables analysed such as the age at the first calving, open days and calving period were included to describe changes in reproductive performance of these cows grazing rice crop residues. Data were put into 2-year groups (1: 1999-2000, 2: 2001-2002, 3: 2003-2004, 4: 2005-2006, 5: 2007-2008, 6: 2009-2010, 7: 2011-2012). Rainfall data from 1999 through 2012, except 2005, were described as a bimodal. Bromatologic analysis was performed to amonificated rice straw and rice straw to indicate the quality of the food consumed by animals.

\section{Statistical Analysis}

Data were analyzed using the software SPSS version 14.0. Descriptive statistic was performed. Mean and mean standard deviation were calculated to describe the reproductive performance of primiparous Cebu cattle (age at first calving and open days) and multiparous Cebu cattle with 2 and more calvings (open days and calving interval) within the period between 1999 and 2012; same analyses were performed for rainfall period variables. Confidence level was $95 \%(p \leq 0.05)$.

\section{Results}

The average reproductive performance of the primiparous Cebu cattle related to age at first calving is $41.05 \pm 1.8$ months and open days mean is $269.7 \pm 36.2$. Regarding to the multiparous Cebu cattle, ( 2 or more parturitions), the open days average is $245.6 \pm 36.84$, and the calving interval average is 17.5 \pm 0.9 months.

Figure 1 depicts the age at first calving trend of the primiparous Cebu cattle. There is a similar behavior from 1999-2000 until 2009-2010, with an average age of 40.5 months at first calving, but this age increases from 39.9 months to 45 months from 2009-2010 to 2011-2012. Open days have a completely different behavior starting with an average of 163 days (5.4 months) that increases until 2001-2002. Afterward this reproductive parameter keeps a steady behavior until 2007-2008 when it increases to 390.58 days in 2009-2010. Subsequently it decreases to 170.75 days in 2011-2012.

The confidence interval is 36.8 - 45.3 months of age at first calving, and 202.7 - 336.6 of open days.

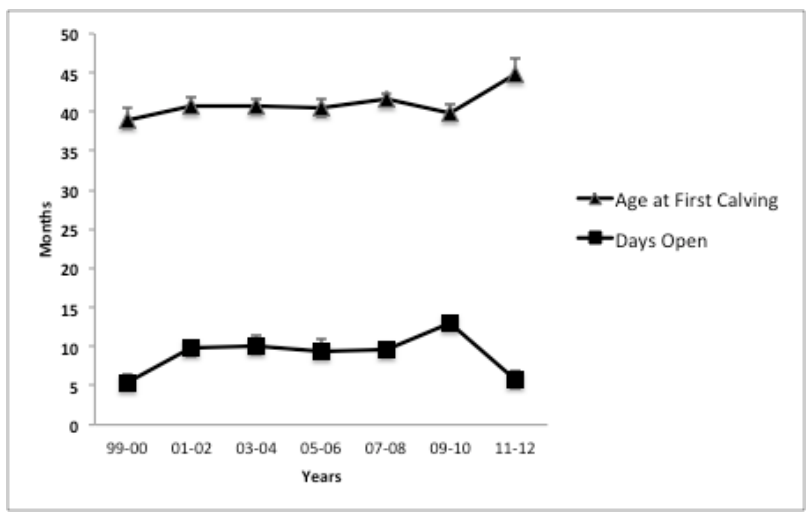

Figure 1.

Age at first calving and open days in primiparous Cebu cows $(n=89)$ from 1999 to 2012 at Hacienda Calicanto, Colombia-South America.
Figure 2 represents the important variation of both open days and calving interval of multiparous Cebu cows from 1999 to 2012.

The confidence interval is 207.2 - 366.9 open days and 13.9 20.7 months of calving interval.

Figure 3 shows the average rainfall between each two-year period since 1999 until 2012.

Table 1 shows the bromatologic quality of the straw consumed by the animals on Hacienda Calicanto. The crude protein of the rice straw supplies the minimum value of protein for the ruminal bacteria maintenance, which means that the probability for these bacteria to grow in ruminal population is low, so the Microbial Protein passing to the posterior digestive tract of the ruminant is eventually minimal.

\section{Discussion}

Reproductive trend of the primiparous Cebu herd of Hacienda Calicanto were similar to those published in 1996; authors reported a mean age at first calving of 38.2 months, (García, Maldonado-Estrada, \& López, 2003; Haile-Mariam \& Makonnen, 1996). Cattle Federation breeders in Colombia (FEDEGAN, 2006), stated that for beef production system in Colombia, the age at first calving was 42 months. Similar results were obtained recently (Khan \& Chowdhury, 2011), with a mean of

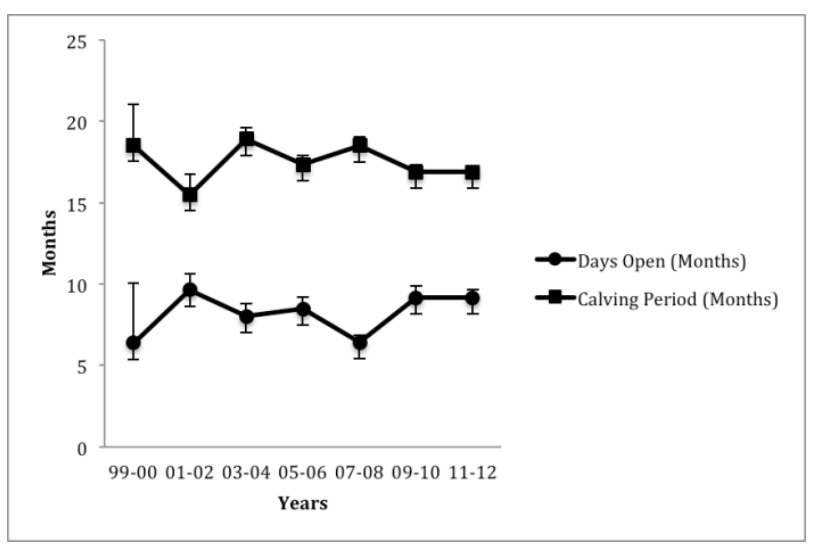

\section{Figure 2.}

Open days (months) and calving interval (months) of multiparous Cebu cows $(n=309)$ from 1999 to 2012 at Hacienda Calicanto, ColombiaSouth America.

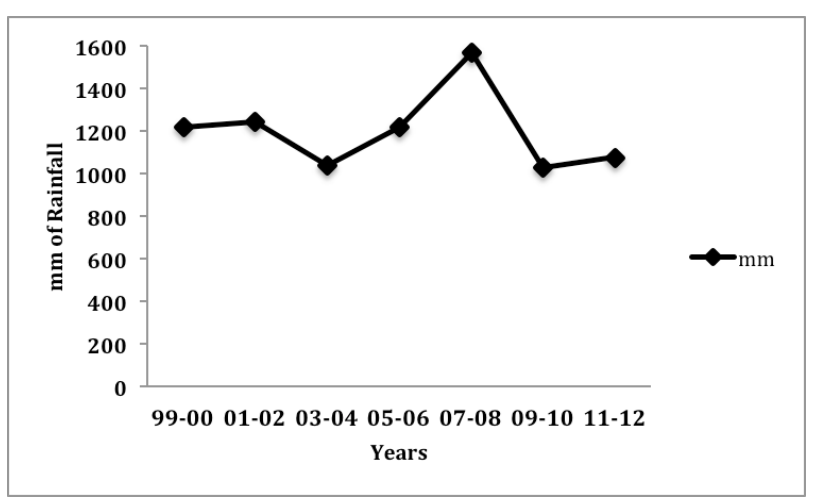

Figure 3.

Average rainfall for 2-year-period from 1999 until 2012 at Hacienda Calicanto, Colombia-South America. 
Table 1.

Bromatologic analysis of rice straw and amonificated rice straw consumed by Cebu cows (398) at Hacienda Calicanto, Colombia-South America.

\begin{tabular}{ccccccccccccccc}
\hline & CP & NDF & ADF & EE & $\begin{array}{c}\text { CALORIFIC } \\
\text { VALUE }\end{array}$ & ASH & CA++ & P & Fe & Mg & Mn & K & Na & Zn \\
& $\%$ & $\%$ & $\%$ & $\%$ & Cal/g & $\%$ & $\%$ & $\%$ & $\mathrm{mg} / \mathrm{kg}$ & $\%$ & $\mathrm{mg} / \mathrm{kg}$ & $\%$ & $\mathrm{mg} / \mathrm{kg}$ & $\mathrm{mg} / \mathrm{kg}$ \\
\hline Rice Straw & 7.5 & 69.1 & 44.3 & 1.06 & 3891 & 15.86 & 0.15 & 0.08 & 103 & 0.13 & 257 & 1.81 & 712 & 21 \\
Rice Straw & 12 & 64 & 38.6 & 1.85 & 3841 & 17.25 & 0.42 & 0.04 & 48 & 0.16 & 177 & 1.27 & 42 & 11 \\
\hline
\end{tabular}

4 months of calving interval for Sahiwal x Cebu cattle grazing rice crop residues.

Regarding to the multiparous Cebu cattle, similar results with 14, 6 months period of calving interval were reported in Sahiwal cattle (Rehman \& Khan, 2012); in multiparous Colombian cattle (FEDEGAN, 2006) 18.3 months and 14.8 months in Cebu cattle grazing Bothriochloa pertusa and Dichantium aristatum in North Colombian Tropical Dry Forest (García et al., 2003).

In Sahiwal x Cebu multiparous cows grazing rice straw 209 open days average was reported (Khan \& Chowdhury, 2011), a similar behavior of the performance of the Cebu cows in this research.

Factors such as suckling stimulus and low nutritional status of the animal (limited dietary energy and protein intake) can explain the long period of open days (Rutter \& Randel, 1984; Wiltbank, 1979).

A similar inter-calving period of Cebu cattle was reported many years ago, where Cebu cows had 19 months of the calving interval (Luktuke \& Subramanian, 1961).

The primiparous Cebu cattle showed a steady reproductive performance until 2009-2010, where this parameter decreased severely. Possibly, this effect could be due to lowest rainfall during this 2-year-period that could have affected the comfort and welfare of the animals. It could have also affected the pasture availability and quality as well as the consumption behavior of the animals, because at low rainfall, high temperatures and radiation are frequently experimented in this life zone. Both high a low rainfall can affect the reproductive performance of the Cebu cattle.

A similar issue could have happened to the multiparous cattle, who in 2004-2005 and 2007-2008 presented the highest calving period of all, possibly because of the lowest rainfall during these years.

\section{Conclusion}

The reproductive trend of the primiparous cattle showed an increasing behavior of age at first calving since 1999 until 2012, that can possibly be explained due to the decreasing behavior of the rainfall throughout the years, that can affect the nutritional value and offer of the grass that can grow in the borders of the crop, such as Guinea and Star grass, and eventually affect the body condition and weight necessary to be ready for the first conception. An inverse behavior of open days occurred, showing a decreased trend along the last years of research. This fact could have happened due to the intensive use of the enriched rice straw with urea and molasses lately.

Concerning the reproductive trend of the multiparous cattle, there is no an evident pattern, which means that factors such as rainfall, temperature, nutrition and management should affect it.
Alternative ways of nutrition of these cows that graze rice crop residues, such as planting fodder trees in the borders of the crop, as Leucaena, Gliricidum sp. are proposed. Further research on this topic has to be done.

\section{Acknowledgements}

The authors acknowledge the owner of the farm, Dr. Alberto Mejía Fortich, who facilitated the research in Hacienda Calicanto, Mr. Jorge Eliecer Robayo, the administrator and the cowboys Jorge, Dionicio and Angel María, who helped during the investigation.

*Proyect: "Investigaciones para el incremento de la productividad silvopastoril y los servicios ambientales en el proyecto Ganadería Colombiana Sostenible” financiado por COLCIENCIAS. Centro para la Investigación en Sistemas Sostenibles de Producción Agropecuaria-CIPAV. Universidad Nacional de Colombia-Sede Medellín, Colombia. Grupo de Investigación BIOGÉNESIS, Facultad de Ciencias Agrarias, Universidad de Antioquia, Medellín, Colombia.

\section{REFERENCES}

Delgado, C., Ehui, S., \& Cour, C. (1999). Live stock to 2020. The Next Food Revolution.

FAO (2009). El estado mundial de la agricultura y la alimentación 2009 (p. 184). ROMA.

FEDEGAN (2006). La vision de Corpoica para el mejoramiento del hato bovino nacional (p. 33).

García, G. A., Maldonado-Estrada, J. G., \& López, J. G. (2003). Caracterización productiva y reproductiva de las explotaciones ganaderas del bajo Cauca y el litoral Atlántico Antioqueños. II. Comportamiento de cuatro grupos raciales Bos Indicus en un sistema de bosque seco tropical (bs-T). Revista Colombiana de Ciencias Pecuarias, 16, 117-126.

Haile-Mariam, M., \& Makonnen, G. (1996). Reproductive performance of zebu, Friesian, and Friesian-zebu crosses. Tropical Agriculture, 73, 142-147.

Khan, M. A. S., \& Chowdhury, M. A. R. (2011). Urea Molasses Blocks to improve milk production and reproductive performance of crossbred dairy cattle under smallholder farm condiction in Bangladesh (pp. 123-124). Bangladesh.

Luktuke, S. N., \& Subramanian, P. (1961). Studies on certain aspects of the oestrus phenomenon in Hariana cattle. Journal of Reproduction and Fertility, 2, 199-200.

Rehman, Z., \& Khan, M. (2012). Environmental factors affecting performance traits of sahiwal cattle in Pakistan. Pakistan Veterinary Journal, 32, 229-233.

Rutter, L. M., \& Randel, R. D. (1984). Post-partum nutrient intake and body condition: Effect on pituitary function and onset of oestrus in beef cattle. Journal of Animal Science, 58, 265.

Wiltbank, J. N. (1979). Research needs in beef cattle production. Journal of Animal Science, 31, 755-762. 